University of Nebraska - Lincoln

DigitalCommons@University of Nebraska - Lincoln

Textile Society of America Symposium

Proceedings

Textile Society of America

$10-2020$

\title{
Signed in Silk and Silver: Examining an Eighteenth-Century Torah Ark Curtain and its Maker
}

Genevieve Cortinovis

Miriam Murphy

Follow this and additional works at: https://digitalcommons.unl.edu/tsaconf

Part of the Art and Materials Conservation Commons, Art Practice Commons, Fashion Design Commons, Fiber, Textile, and Weaving Arts Commons, Fine Arts Commons, and the Museum Studies Commons

This Article is brought to you for free and open access by the Textile Society of America at DigitalCommons@University of Nebraska - Lincoln. It has been accepted for inclusion in Textile Society of America Symposium Proceedings by an authorized administrator of DigitalCommons@University of Nebraska - Lincoln. 


\section{Signed in Silk and Silver: Examining an Eighteenth-Century Torah Ark Curtain and its Maker}

Genevieve Cortinovis and Miriam Murphy

In the Hebrew year 5515 or about 1755, in Ancona, a port city on the Adriatic coast of Italy, the young woman Simhah Viterbo embroidered a dedicatory inscription in Hebrew across the lower edge of this splendid Torah ark curtain or parokhet (Illustration One). It reads, "handwork of the young woman Simhah Viterbo in year of the straight and good," the latter phrase a chronogram revealing the date. ${ }^{1}$ Viterbo, about sixteen at the time, was continuing in a long tradition of Italian Jewish women who, as acknowledged in a prayer in the Italian rite, fashioned "a mantle or cover with which to adorn the Torah."2

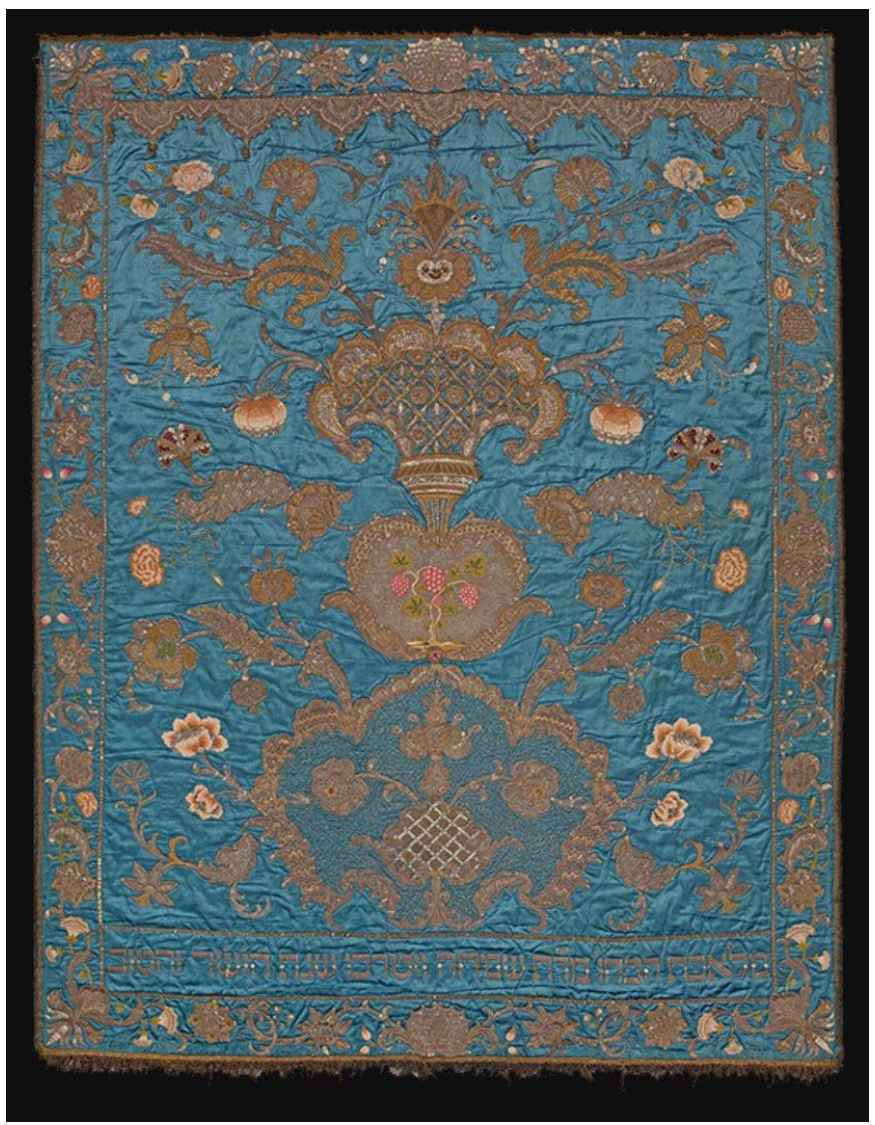

1.Simhah Viterbo, Italian, 1739-1779, Torah Ark Curtain, Ancona, 1755 [515], Saint Louis Art Museum 2:2019

Drawing upon documentary sources of the Jewish community held primarily in the Central Archives for the History of the Jewish People (CAHJP) in Jerusalem, a group of Italian and Ottoman eighteenth-century Torah ark curtains, and the Inventory of Historical and Artistic Heritage of the Diocese of Ancona, this paper considers Viterbo's potential design sources and influences, in order understand how this remarkably hybrid textile reflected her Jewish heritage

\footnotetext{
${ }^{1}$ The date is given as a chronogram "hayashar v'hatov" or "year of the straight and good" and can be understood using the Gematria system of Jewish numerology by which a letter in the Hebrew alphabet corresponds to a numerical value, in this case 515, with the 5000 implied.

${ }^{2}$ Maazor kol ha-shanah ke-fi minhag Italyani, ed. Samuel David Luzzatto (Livorno, 1855), 45r.
} 
but also her place and time, at the center of a major (and now overshadowed) Mediterranean trading crossroads during an era of increasing connectivity.

\section{Historic Background}

The largest and most conspicuous of synagogue textile furnishings, the parokhet hangs in front of or sometimes inside the Torah ark, an ornate cabinet that houses the sacred Torah, the first five books of the Hebrew Bible, and thus acts as the focal point of prayer. This painting of a synagogue interior from the seventeenth century shows a red and silver curtain with gold trim, hanging from the Torah ark visible on the right side (Illustration Two). The women look on from an elevated gallery. The men wear yellow hats, a discriminatory mandate, that suggests this depicts a synagogue in a Papal State, not unlike the one Viterbo attended.

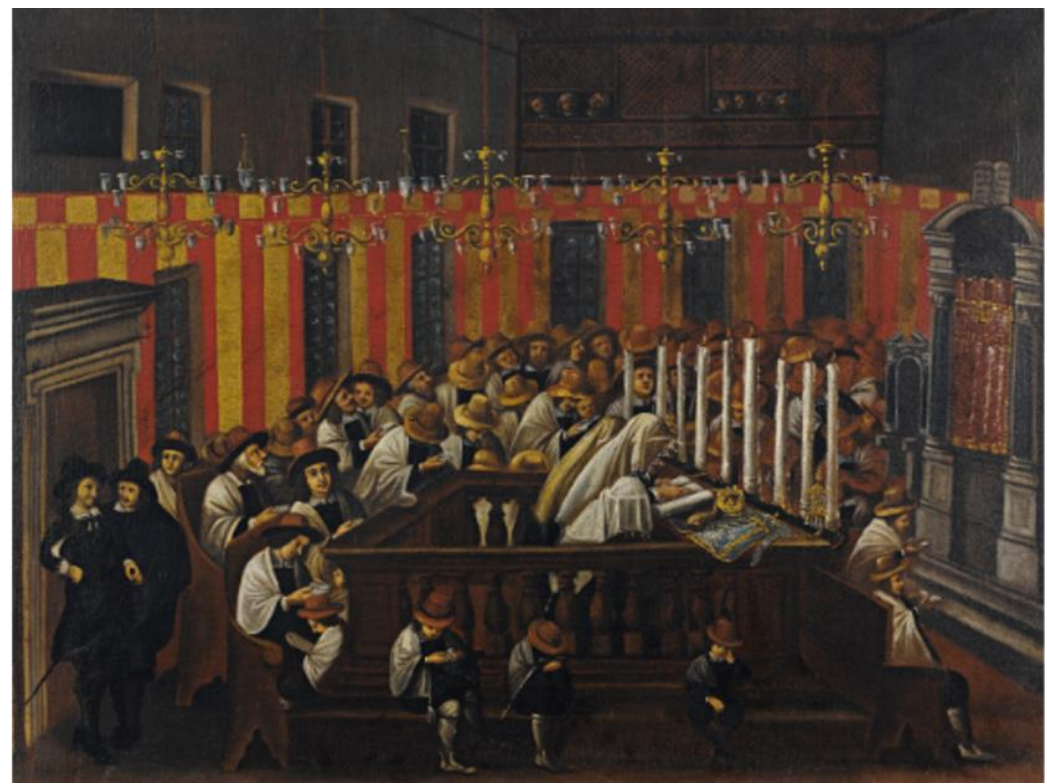

2. Italian School, Prayer in the Synagogue During the High Holy Days, probably the Papal States, seventeenth Century, Private Collection

As a Papal State, Ancona was under the direct sovereign rule of the Pope. In 1555, the Papal Bull Cum nimis absurdum, among other indignities, severely restricted the professional and economic freedom of Jews living in the Papal States, forcing most into just a few predominantly low-skill trades, like second-hand textile dealing and segregating them in ghettos. Although expressly prison-neighborhoods, scholar Dora Liscia Bemporad has suggested they also paradoxically offered security from what had been a constant threat of expulsion. This continuity of place coupled with the forced isolation of diverse communities of Jews together in a confined area "favored the growth, if not the birth, of ceremonial art that enriched and embellished places of worship to a degree that went beyond ritual needs." 3

The Jewish community of Ancona, like elsewhere in Italy, was comprised of three main cultural groups: Italianate, Sephardic, and Ashkenazic Jews. Sephardic Jews largely arrived after 1492, fleeing persecution and eventual expulsion from Spain and Portugal. With them, came increased

\footnotetext{
${ }^{3}$ Dora Liscia Bemporad, "Jewish Ceremonial Art in the Era of the Ghettos" in Gardens and Ghettos: The Art of Jewish Life in Italy (Berkeley and Los Angeles: University of California Press, 1989), 111.
} 
trade with the East, thanks to familial networks established by Sephardic Jews across the Ottoman Empire. These networks benefitted Ancona and despite always remaining a mid-size port, at three different moments in its history, the city enjoyed moments of economic prosperity. One such moment was in the mid eighteenth century, thanks in large part to its designation as a free port in 1732. Free ports were open to captains or merchants from any nation, luring them with the customs-free sale, storage, and reexport of goods. While economic historian Luca Andreoni suggested the city's new status did not particularly benefit Jewish traders since it attracted French and English competition, it resulted in an influx of goods and people from across Europe. Ancona was also the export port for the agricultural goods of the Marche, which included cereals and raw silk, consistently attracting foreign traders. ${ }^{4}$

Bemporad suggests that experience in the textile trade, whether as shopkeepers like Anconite Consola Cinquecento who in 1739 sold "new and old linens, lace, and indiane [printed and painted cotton textiles]," or practitioners of rinacciature, or expert mending, probably spurred increased professionalism in textile crafts like embroidery. ${ }^{5}$ And, while initially limited to an internal market, by the seventeenth century, Jewish professional embroiderers likely catered to customers outside the ghetto. ${ }^{6}$ The documented evidence of their work, thanks primarily to inscriptions, was made for the synagogue, the center of Jewish life in Italy. Gifts of Torah ark curtains, mantels, binders, wrappers, and desk covers, often fashioned from repurposed luxury textiles, were frequently gifted to commemorate significant events in the life of a family.

While Viterbo's Torah curtain has intermittently been attributed to Ancona since it was first published in 1986, her identity, including the date and place of her birth and death and family members had not been determined. Birth and death records in the CAHJP revealed that she was born on June 10, 1739 to Shelomo Mose Viterbo (Solomon Moise) and died on June 8, 1779. ${ }^{7}$ Her father was a student of the famed rabbi and physician Samson Morpurgo and likely a smallscale wool importer. Thanks to a recent discovery by Gioia Perugia at the Israel Museum in Jerusalem, we know that Viterbo made two other synagogue textiles, a Torah mantle in 1750 and a Torah wrapper in 1758 , both in a private collection. The double appellation "ha'bachura marat" used in the inscription on the curtain indicates among Italian Jewry that Viterbo was not married at the time of its construction. Although the Archivio Notarile di Ancona does not contain a record of Simhah's marriage, CAHJP files confirm she gave birth first to a daughter Ferna with Mordechai Rafael Shimshon Zemach Viterbo (Angelo Sansone) in 1764 and then to two sons. She died at the age of 40, leaving a twelve-year-old son, Yechiel Hayim Viterbo (Vitale Vita), who would go on to become a noted rabbi and write about her extraordinary artistic talents. In an 1818 text, he muses, "the work of her hands was magnificent, words cannot describe ... with works of art, embroidery, in silver and in gold, more valuable than pearls, for the grandeur of the

4 Luca Andreoni, “Una Nazione in Commercio” Ebrei di Ancona, traffic adriatici e pratiche mercantile in età moderna (FrancoAngeli, 2019), 258. Altogether, from 1736-37, Jewish traders accounted for about $13 \%$ of the port trade, which aligned more or less with their demographic numbers.

5 Andreoni, "Una Nazione in Commercio" Ebrei di Ancona, traffic adriatici e pratiche mercantile in età moderna, 258.

${ }^{6}$ Dora Liscia Bemporad, "Ricamtrici ebree nell'Italia dei ghetti” in Donne nella storia degli ebrei d'Italia (Firenze: Giuntina, 2007), 301-303.

${ }^{7}$ CAHJP IT/An 98, IT/An 107, and IT/An 99. 
sanctuary and the court." ${ }^{\text {T }}$ This poetic tribute, laden with biblical references, is a rare document celebrating the work of a specific woman embroiderer. It suggests Viterbo continued her artistic practice after she was married and thus many more of her embroideries could survive today.

According to historian Michaël Gasperoni, trousseaux of women in the Marche were particularly well equipped and included books and ritual objects. ${ }^{9}$ Although Viterbo's dowery record has not been identified, as a rabbi, Simhah's father certainly owned books, including one printed in Venice by Bragadina in 1620. It commences with a distinctive title page composed of a portal with double columns and a broken pediment. Scholars suggest these so-called gate pages influenced the design of contemporary Torah arks and curtains. Ancona's Italian-rite synagogue constructed in 1635 and presumably attended by Viterbo boasted a Torah ark with helical columns and silver repoussé doors featuring sunflowers rising from a gadrooned urn and side panels of floral garlands (Illustration Three). While austere on the exterior, the synagogue's interior mirrored the opulence and to some degree the design of nearby Baroque churches. ${ }^{10}$ This engagement with dominant gentile culture was tempered by a desire to create uniquely Jewish spaces of worship, a sensibility that is evident in Viterbo's curtain.

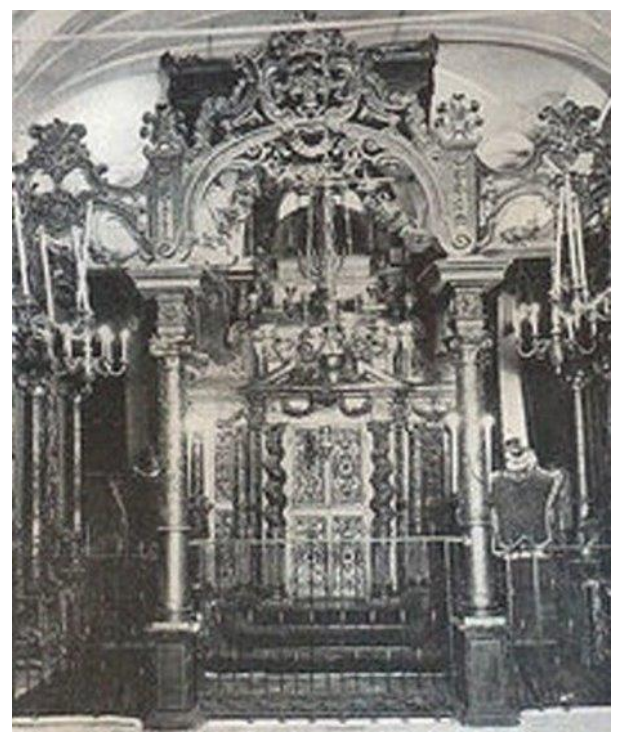

3. Photograph of the Torah ark of Ancona's Italian Synagogue,

Umberto Nahon Museum of Italian Jewish Art, Jerusalem

\footnotetext{
${ }^{8}$ Yechiel Hayim Viterbo, Sefer Va-yehi 'od (Livorno: Otolenghi, 567 [1817 or 1818]), 7. The last paragraphs of the introduction of the book reads: "I was a child, tender and my mother's only ... And together we used to have great fun every day ... She was taken from me when I was almost fourteen ... A woman of valor, of many talents, the splendor of man ... She kept order among many different things, the work of her hands was magnificent, words cannot describe; female wisdom built her house. . . with works of art, embroidery, in silver and in gold, more valuable than pearls, for the grandeur of the sanctuary and the court." The inclusion of "court" in the text is likely a biblical reference and does not suggest a secular court. A complex text, this requires more analysis and will be the topic of future paper.

${ }^{9}$ Michael Gasperoni, "Inheritance and wealth among Jewish women in the ghettos of north-central Italy (17theighteenth centuries)," Mélanges de l'École française de Rome - Moyen Âge, 130-1 (2018), 28.

${ }^{10}$ Rivka Dorfman and Ben-Zion Dorfman, Synagogues without Jews (Philadelphia: Jewish Publication Society, 2000), 20-21.
} 


\section{Materials and Techniques of Manufacture}

This Torah ark curtain measures 87 inches $(221 \mathrm{~cm}$.) long by 66 inches $(168 \mathrm{~cm}$.) wide and is composed of three fabric layers: a ground, an underlining, and a backing. Its ground fabric is satin-weave silk, which was underlined with a coarse bast fiber plain-weave fabric (Illustration Four). This fabric added body to the dress-weight silk satin so it would hang as a panel, as well as provided a stabilizing base for the dense and weighty embroidery. The finished curtain was backed with linen plain-weave cloth.

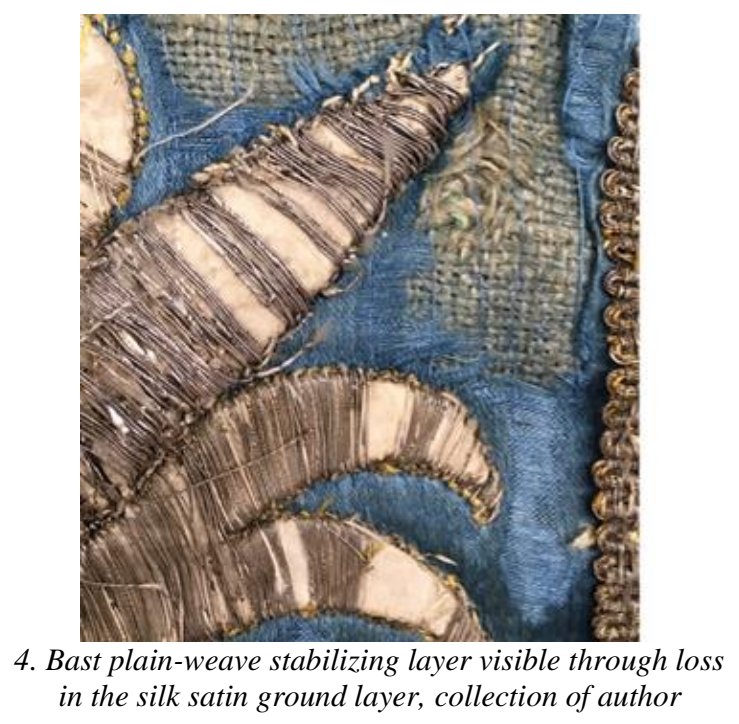

To prepare a lightweight ground fabric for embroidery, the ground and underlining fabrics are tensioned together in a frame. Next the design is temporarily marked, possibly in this case by pouncing powder through a pierced pattern. Padding materials, such as vellum, wool roving or felt, or laid or stitched yarn can then be applied to areas where dimension is desired before being covered with appliquéd fabric, or silk or metal thread embroidery (Illustrations Five and Six).
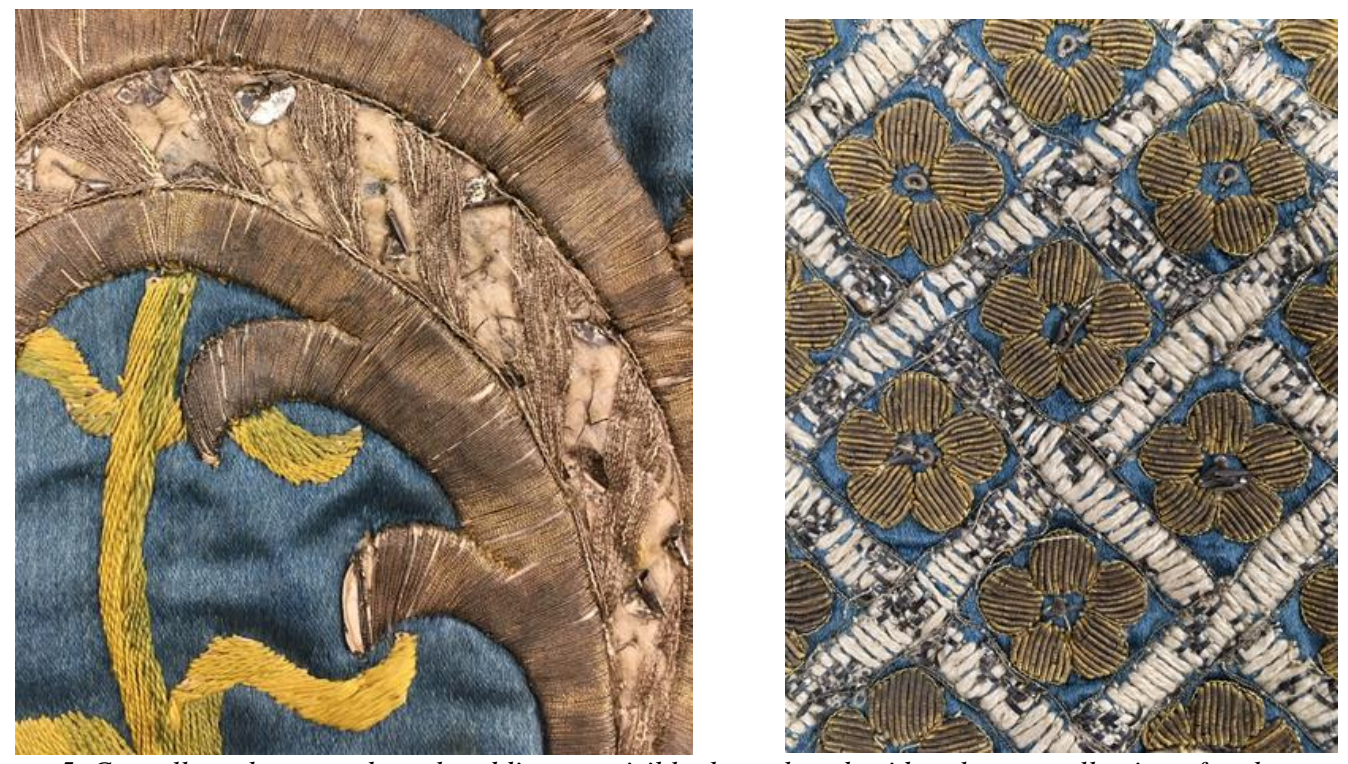

5. Cut vellum shapes and wool padding are visible through embroidery losses, collection of author 6. A latticework of short parallel yarn stitches once gave dimension to strips of metal plate, collection of author 
The fabrics Viterbo used for her appliqués are a red silk velvet, and a green silk satin. There is little fabric appliqué on this Torah ark curtain compared with the amount of metal thread embroidery.

The silk shading work, also known as thread or needle painting, is embroidered next because the silk yarns could catch on the metal embroidery elements during the stitching if they were in place first. Silk shading is accomplished with long and short stitches of silk thread (Illustration Seven). The spans of the stitches create a lustrous surface and their interspersing optically blends and shifts the colors. The stitches can be worked all in one direction or can be angled to suggest the shape of the subject. The silk can be un-plied silk fiber reeled straight from the silkworm cocoon, or a plied yarn as Viterbo used for this Torah ark curtain.

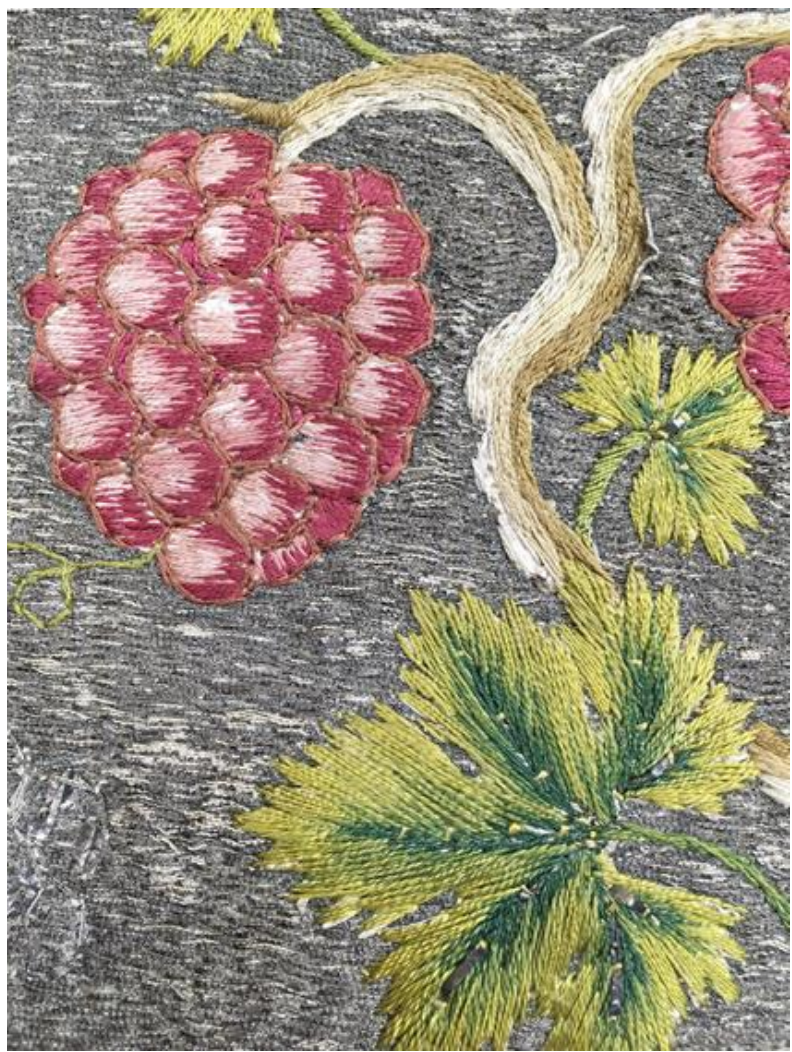

7. Silk shading worked in one direction, and worked at angles, collection of author

There are many combinations of metal thread embroidery stitches (also known as goldwork even when the metal is not gold) on this 35-square foot textile. Unlike modern metallic thread which is commonly made with foiled paper wrapped around a yarn core, metallic threads in Viterbo's time contained metal. The metal could be silver, gold alloy, or silver, gold, or gilt plate over a base metal. Often different stitches are layered to give the embroidery even more dimension.

The metal can take the form of wire, plate, or sheets. Because the metal is so thin it breaks easily which is why much of the metal thread embroidery of this Torah ark curtain was lost over time. When new it would have dazzled in the candlelight of the synagogue. The untarnished metals would have reflected light, and the distinct colors, textures, and thicknesses of the metal threads and their padding would have caused the light to reflect in diverse ways across the surface. 
"Passing," or metal thread, is created by wrapping finely drawn metal around a yellow, grey, or white yarn, depending on the color of the metal, in the opposite direction of the yarn's ply (Illustration 8). The fiber core of the passing is visible where the metal wraps are separated or lost (Illustration Nine).

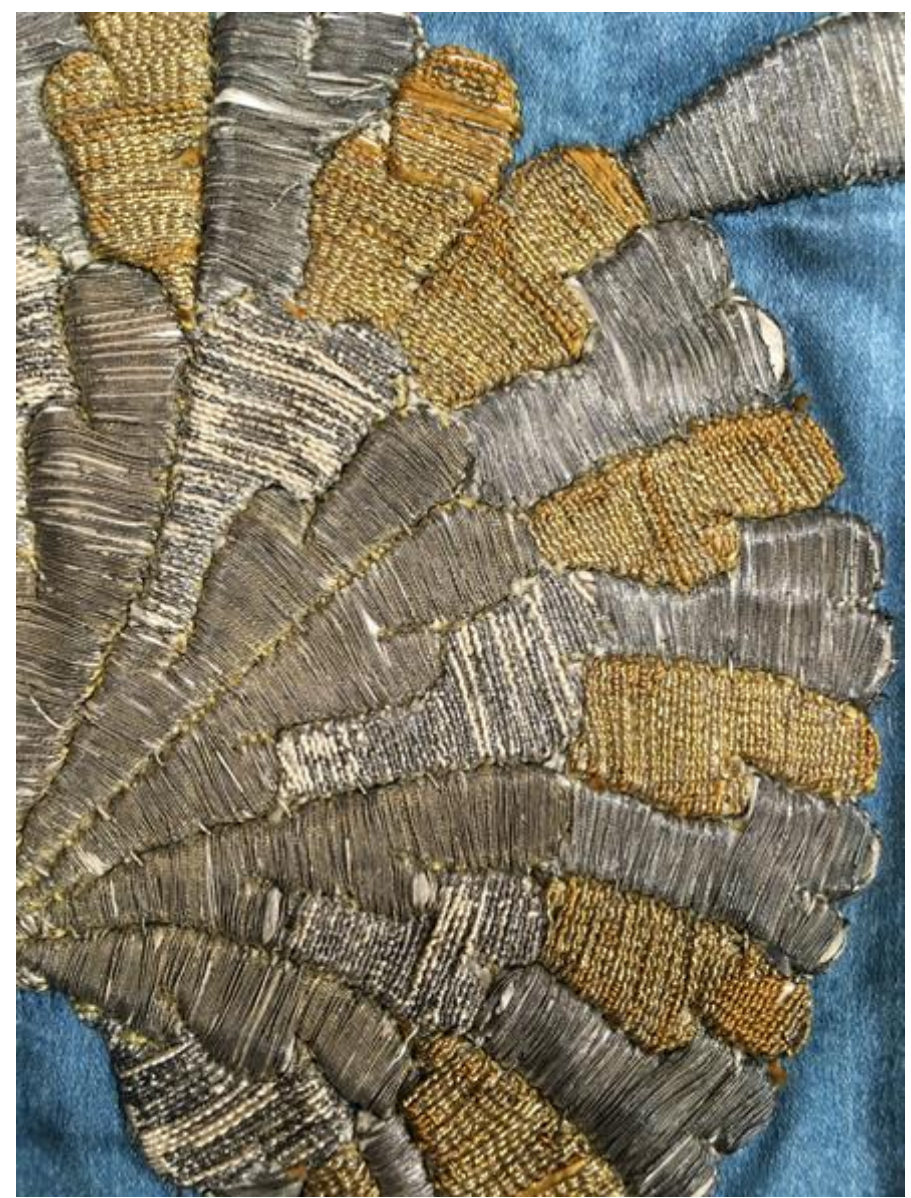

8. Three types of passing create assorted colors and textures, collection of author

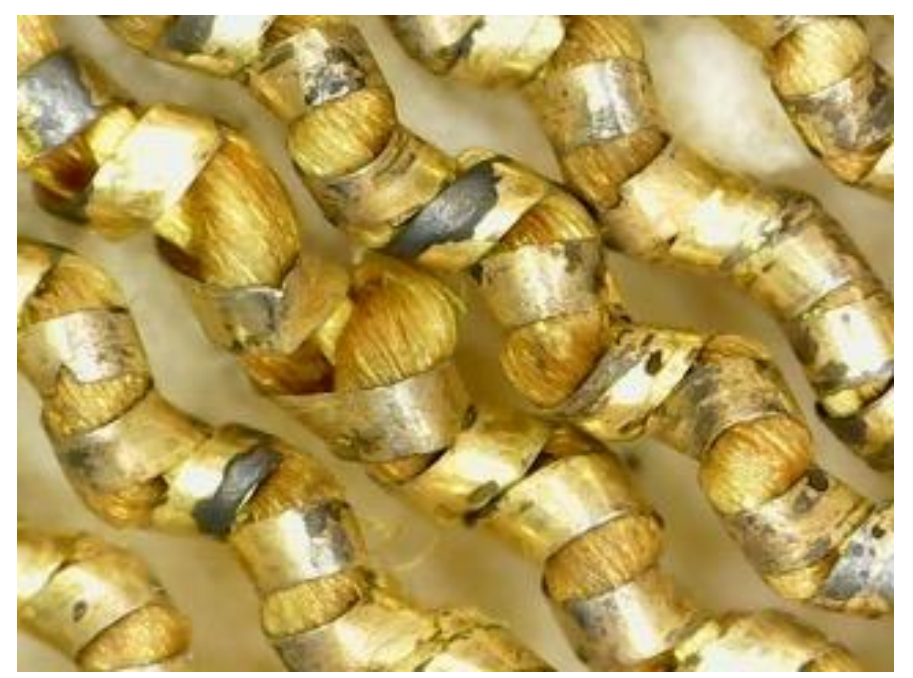

9. Macro image of the gold-plated metal passing shown in 8, collection of author 
Plate, also known as broad plate, is made by flattening wire into a strip. Illustration 10 is a macro image of metal plate which is $1 / 32$ of an inch wide. The yellow "ropes" across the surface are the plied silk yarns couching it in place. Illustration 11 shows overlapped silver plate over padding in the motifs, as well as gold-plated plate couched down to the ground fabric in a lattice pattern around them.

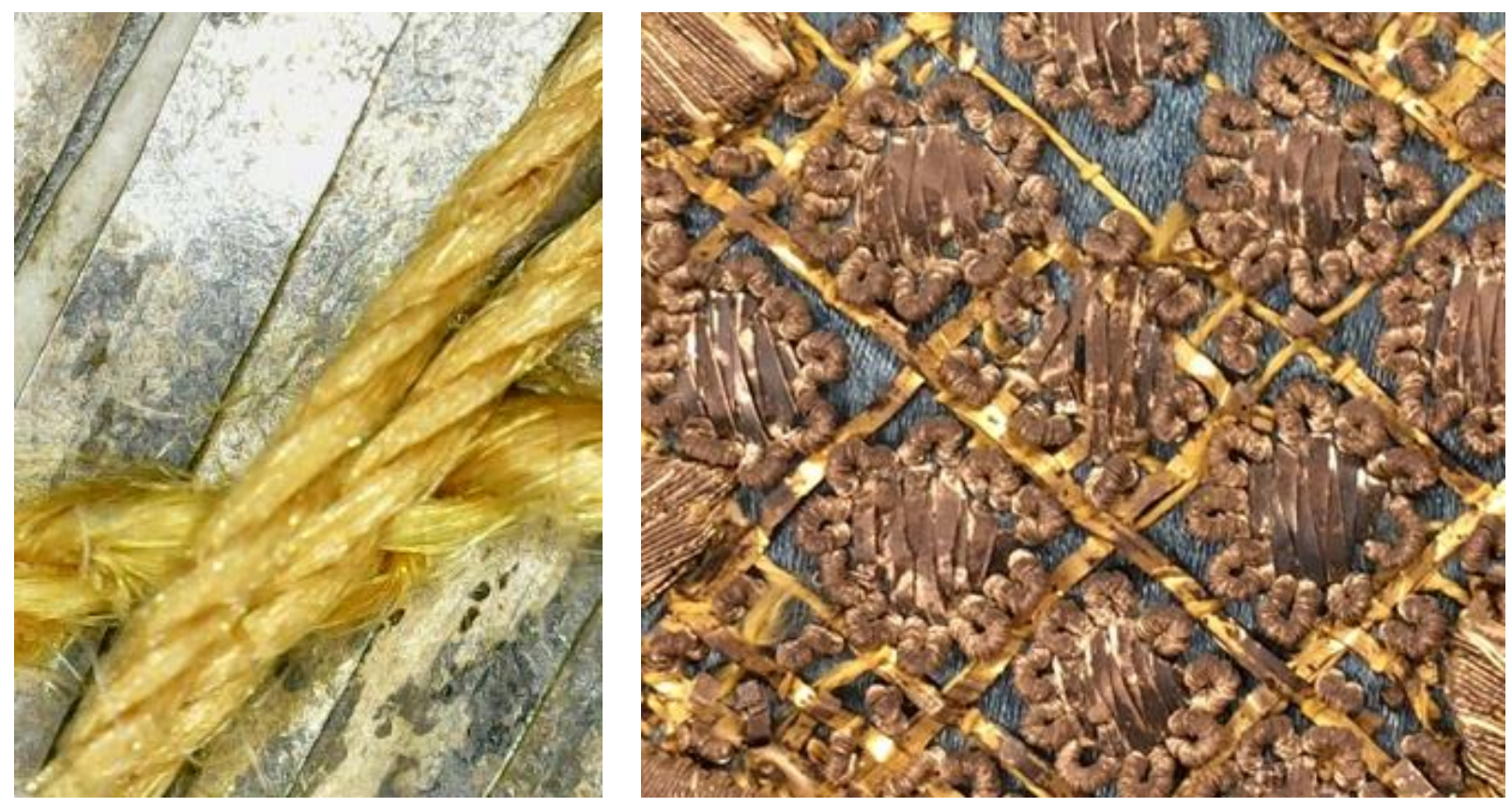

10 and 11. Collection of author

Metal wire coiled into spirals is called purl or bullion. The spirals can be left in a tight coil or pulled apart for an airier appearance (Illustrations 12 and 13).
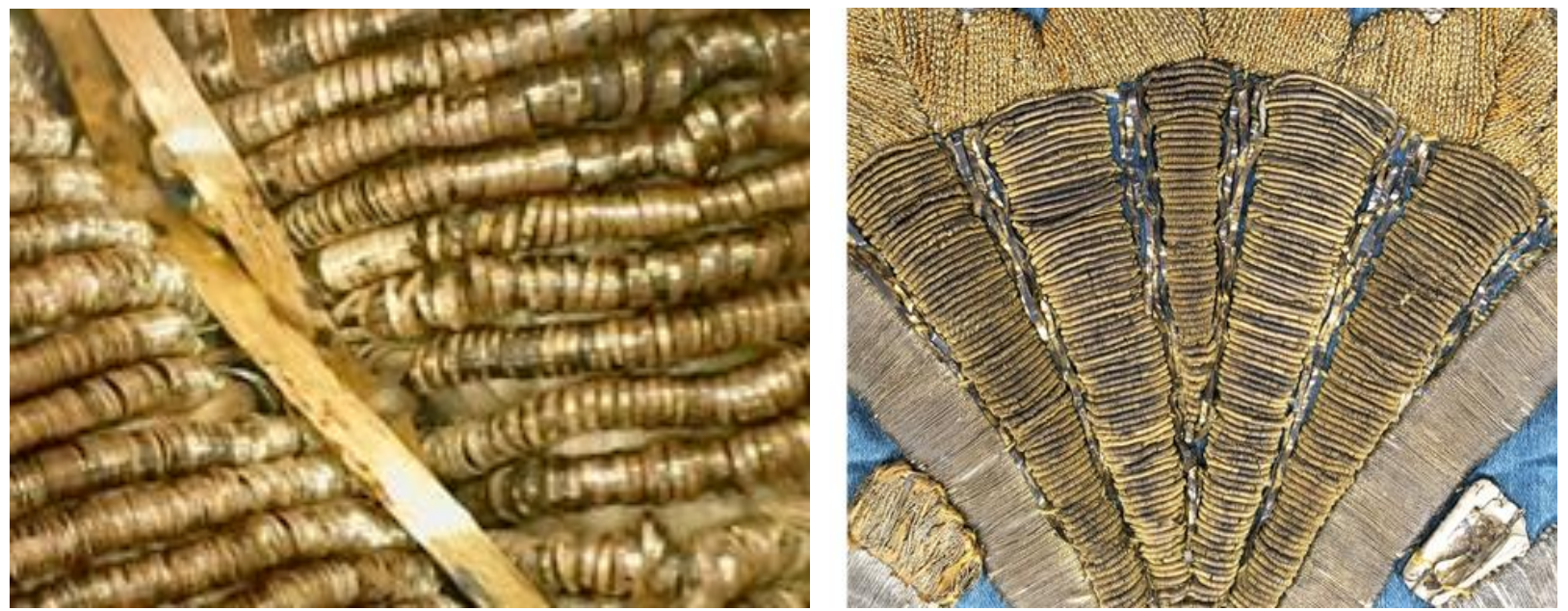

12. Macro image of the purl shown in 13 (right), collection of author 
When purl is cut into very short sections they are called "chips." The chips can be stitched in straight lines, curves, or rings directly on to the ground fabric, or layered over appliqués or other metal thread embroidery. (Illustrations 14 and 15).

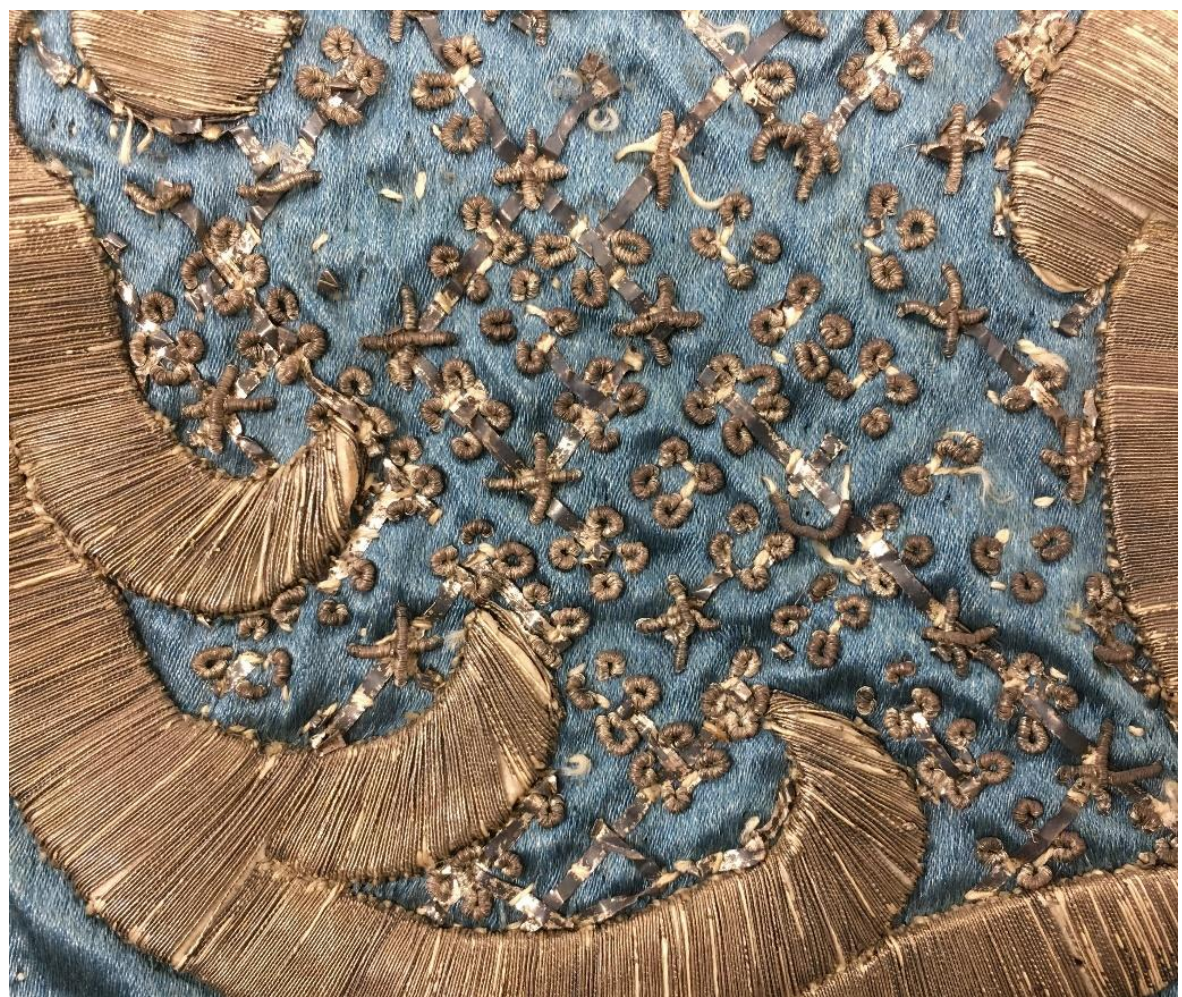

14. Chips in a pattern of Xs and groups of four rings originally held a latticework of plate against the ground fabric, collection of author

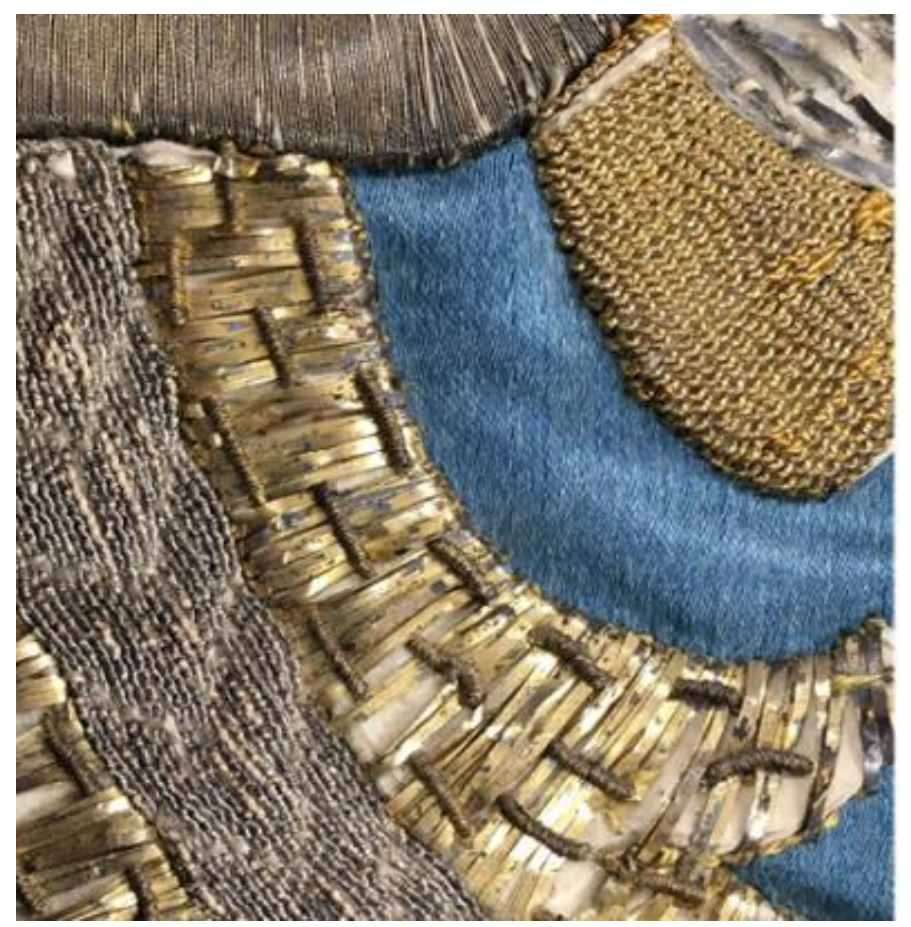

15. Chips decoratively stitched over rows of padded plate, collection of author 
Spangles are also known as paillettes, paillons, or sequins and the terms tend to be used interchangeably. They can be created by coiling wire, then hammering it flat, which creates spangles with a slit opening, or they can be cut or punched from a thin sheet of metal, with a hole punched wherever desired. Spangles can be attached with multiple stitches through the opening and/or or sewn in place through a chip or bead. Viterbo frequently applied the spangles on this Torah ark curtain over a circle of vellum to make them stand out (Illustration 16).

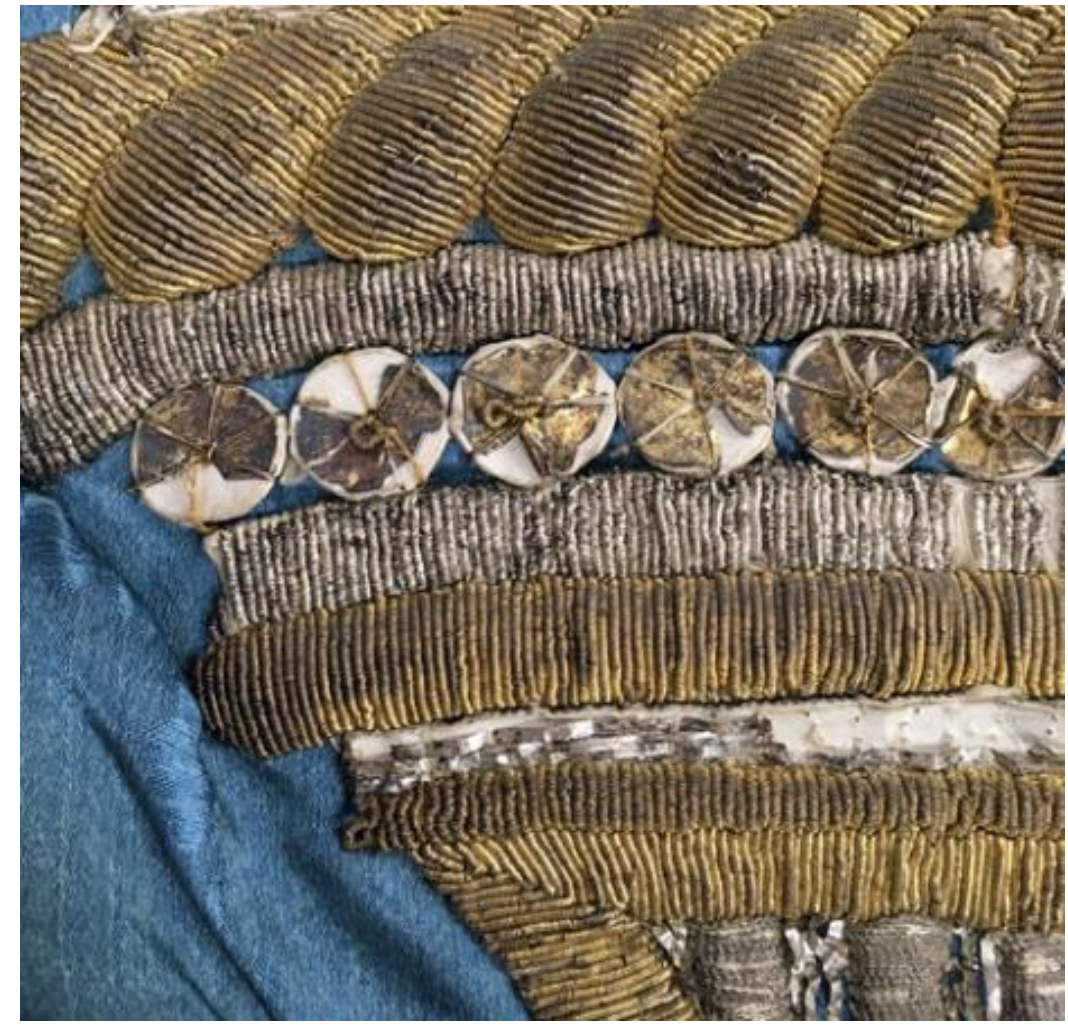

16. Spangles with chips over vellum padding, collection of author

All the elements of goldwork must be couched to the textile. The lengths and shapes are cut and laid in place and couched down with tiny stitches across the metal or through its shaped structure. When the work is done the ends of the metal threads and plates are "plunged" by poking them to the reverse of the ground fabric, through a small hole pierced by an awl or with the aid of a large-eyed needle. To secure the work the plunged ends are couched against the reverse through only the underlining fabric.

\section{Design and Comparatives}

It is instructive to consider comparative eighteenth-century Torah curtains from Venice and Mantua, neither with traces of reuse, which both show variations on a typical floral composition: open wide, scrolling borders that blossom at the corners. The example from Mantua has a fluted vase spilling over with a variety of flowers in a loose, asymmetrical arrangement (Illustration 17). The Venetian example includes tablets of the Covenant surrounded by a glory of clouds, a common motif on seventeenth and eighteenth-century Torah ark curtains brought to Italy by Ashkenazic Jews (Illustration 18). Like Viterbo's parokhet, the Venetian curtain has lavish guipure embroidery, in the mode of Charles Germain de Saint Aubin, but it is rendered entirely in metal threads with no additions of polychrome embroidery or velvet appliques. 


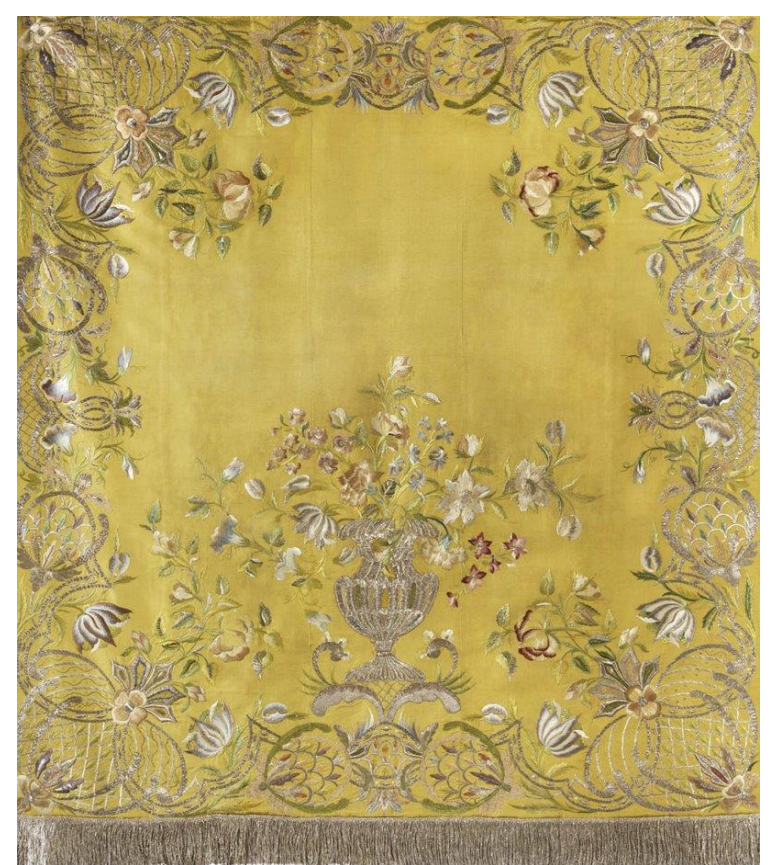

17. Italian, Torah Ark Curtain, Mantua, eighteenth century, Umberto Nahon Museum of Italian Jewish Art, Jerusalem

When comparing Viterbo's curtain to the example from Mantua, several important distinctions become clear. While they both include naturalistic polychrome flowers, Viterbo's metal flowers, varyingly stylized belie a singular source. Viterbo's design stands out for its ordered, architectural approach to a botanical theme. Its central composition, a mass of stacked cartouches, shells, and diapered baskets, supports a balanced arrangement of flowers, and its flower border is narrow and enclosed.

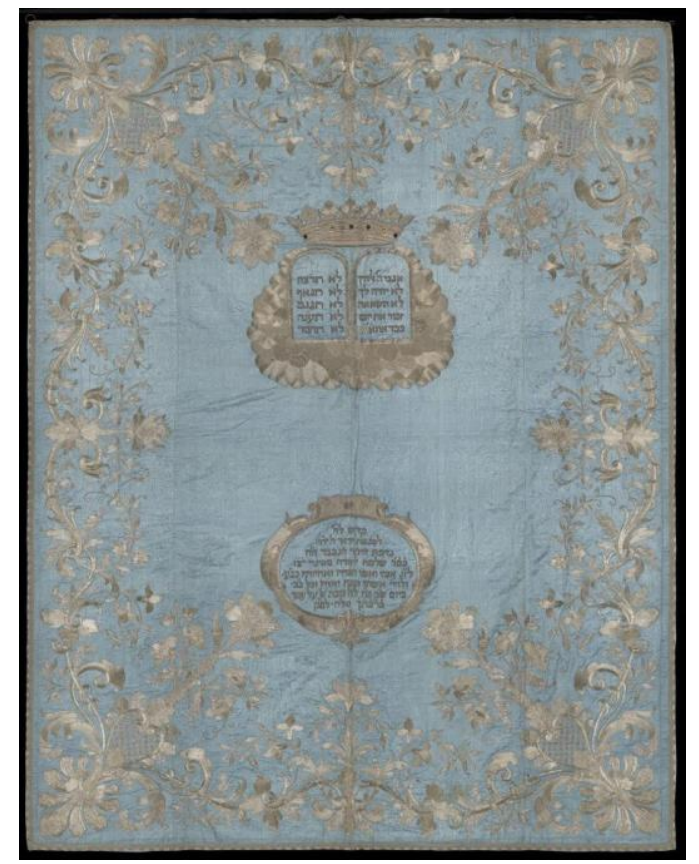

18. Italian, Torah Ark Curtain, Venice, eighteenth century, Museo Ebraico di Roma 
Indeed, I argue it shares some key elements with a group of Ottoman eighteenth-century embroidered Torah curtains made primarily in Istanbul, Yanina, and Thessalonica in northeastern Greece. This example in the collection of the Jewish Museum in New York shows a typical design adopted from an earlier prayer rug form (Illustration 19). A vase of symmetrically arranged flowers, some recognizable and others abstracted, is set within a niche evoking the mihrab and surrounded by a narrow, enclosed scrolling floral border. The triple arched mihrab references woven prayer rugs like this couple-columned example in the Saint Louis Art Museum's collection (Illustration 20). Scholars Walter Denny and Vivien Mann have suggested the coupled column motif, which also appears on woven Torah curtains, is a characteristic of Nasrid architecture brought to the Ottoman Empire via Jewish weavers fleeing Spain in the fifteenth century. ${ }^{11}$ The pastel palette, inclusions of flowers like carnations and roses and Cyprus trees calls to mind embroidery on smaller domestic textiles. As attested by the French merchant Pierre de La Roque, the muslin napkins with gold and silver borders were imported into Europe, along with coffee, in the late seventeenth century. ${ }^{12}$
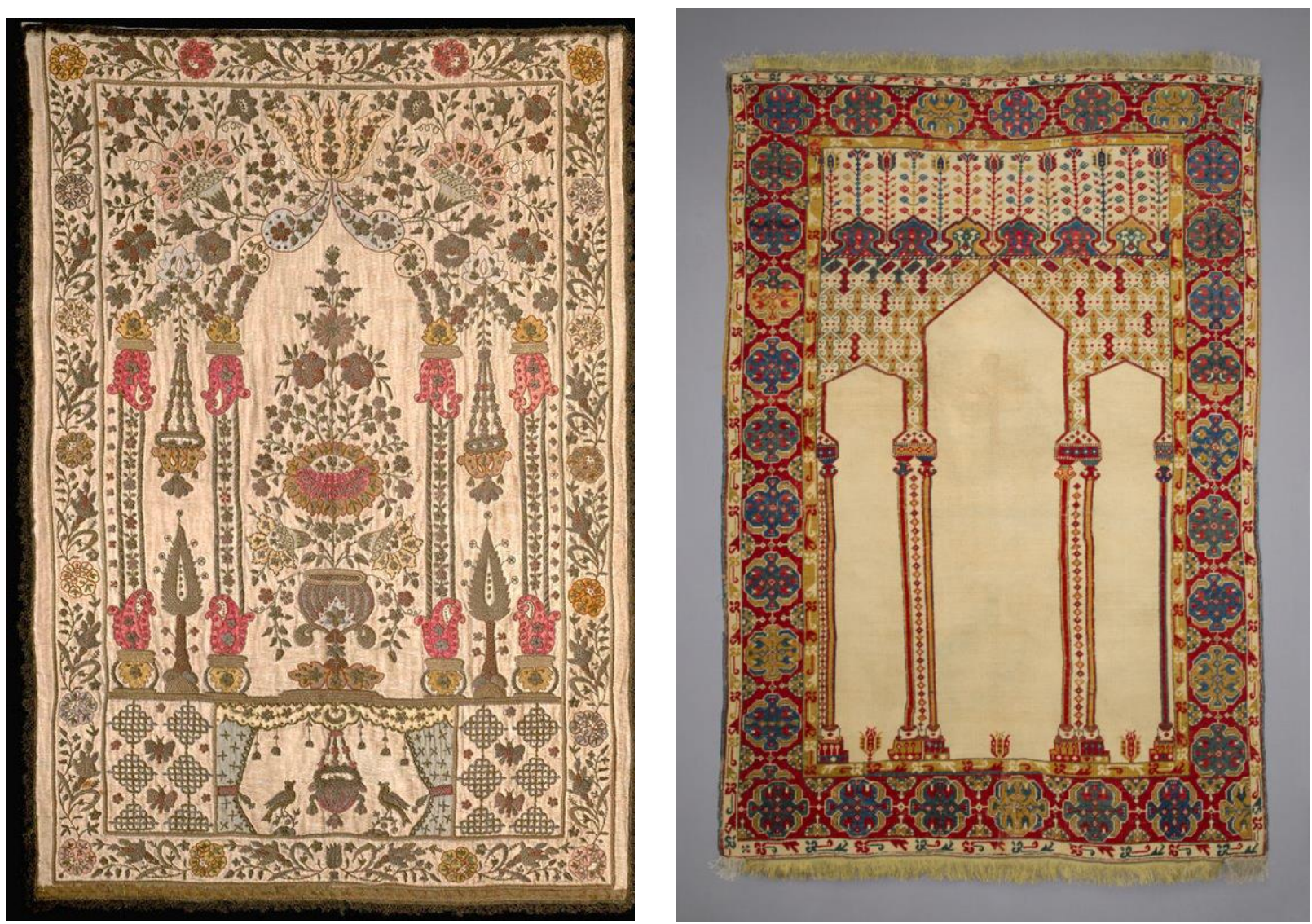

19. Ottoman Period, Torah Ark Curtain, eighteenth century,

The Jewish Museum, New York S 450

20. Ottoman period, Coupled-column Prayer Rug,

Kula, Turkey, eighteenth century, wool; Saint Louis Art Museum 113:1929

\footnotetext{
${ }^{11}$ Vivian B. Mann, "Textiles Travel: The Role of Sephardim in the Transmission of Textile Forms and Designs," in From Catalonia to the Caribbean: The Sephardic Orbit from Medieval to Modern Times -Essays in Honor of Jane S. Gerber, ed. Federica Francesconi, et al. (Leiden: Brill, 2018), 54-56.

${ }^{12}$ Alexander Bevilacqua and Helen Pfeifer, "Turquerie: Culture in Motion, 1650-1750," Past \& Present, no. 221 (November 2013): 95.
} 
Like Venice, Ancona emerged in the sixteenth century as one of the first European cities to have a merchant colony from Ottoman territories, primarily composed of Greek and Jewish traders. Those trade connections remained strong into the eighteenth century. From 1737-38, the greatest number of ships with orders from Anconite Jews overwhelmingly came from Ragusa, presentday Dubrovnik in Croatia, closely followed by Thessaloniki and included tobacco, wool, raw cotton, and textiles. ${ }^{13}$ These two Torah ark curtains with a near identical twisted, or Solomonic, column motif illustrate the shared visual language of Jews living on the Eastern Adriatic and Mediterranean. The light blue example was made in Venice in the seventeenth century (Illustration 21) and the yellow example with a depiction of the Blue Mosque was made in Istanbul a century later (Illustration 22).
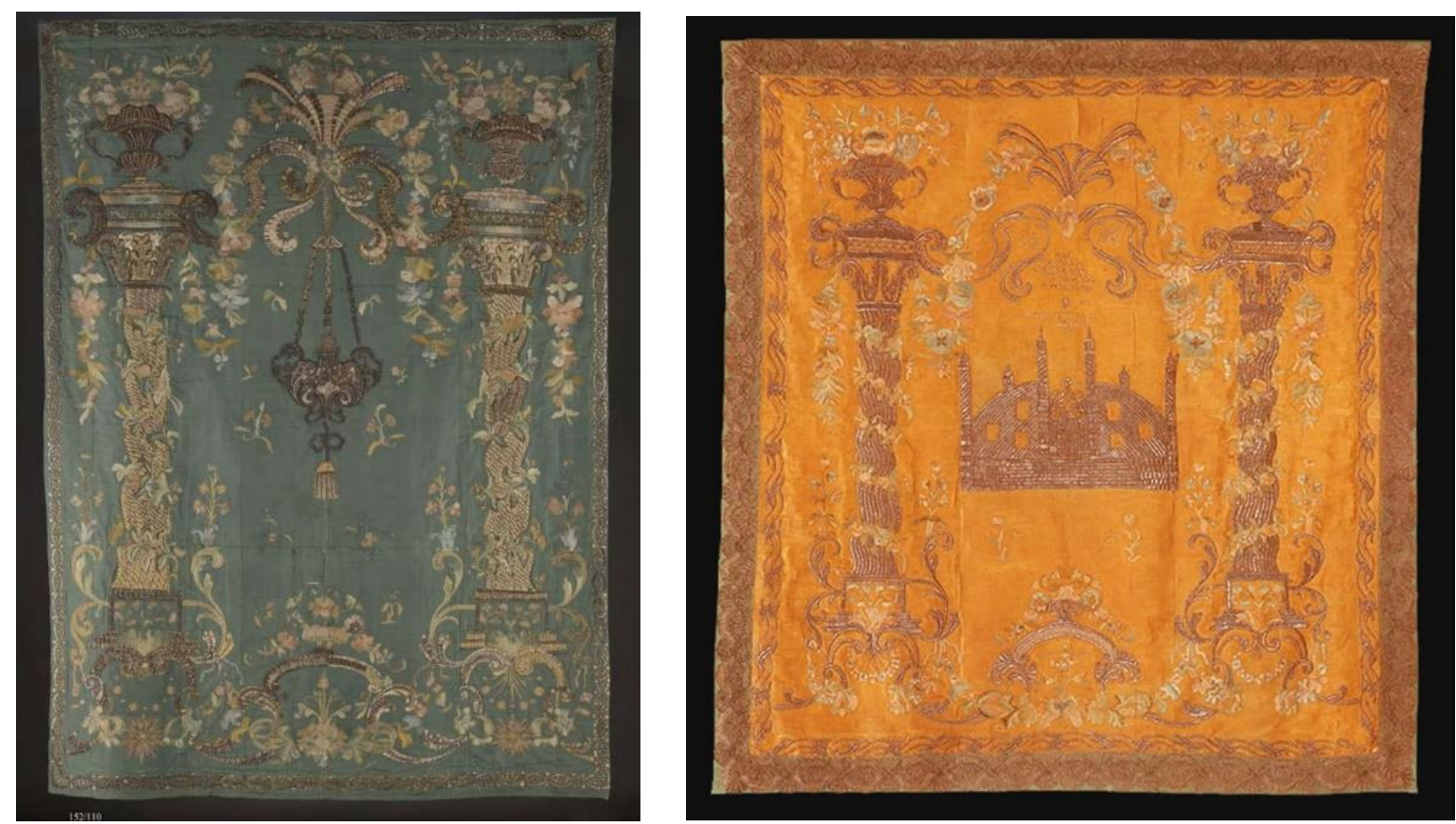

21. Italian, Torah ark curtain decorated with Eternal Light, Venice, Italy, Seventeenth century, The Israel Museum, Jerusalem, B68.0059 22. Ottoman Empire, Torah Ark Curtain, Istanbul, Turkey, c. 1735, The Jewish Museum, New York, 4

Sacred Jewish textiles became increasingly lavish and technically complex beginning in the seventeenth century. By the end of the century, as was the case with synagogue architecture, the opulence and design of Jewish sacred textiles closely mirrored those used in a Christian context. The diocese of Ancona houses several mid eighteenth-century embroidered chasubles featuring asymmetrical curls of scrolls and shells intermixed with colorful roses, carnations, and tendrils of campanula in silk satin (Illustration 23). These florist flowers, also present on Viterbo's Torah curtain, are adopted from the many botanical illustrations made across Europe beginning in the mid seventeenth century. They also dominated the decoration of ketubah, or Jewish marriage contracts, for which Ancona was a major producer.

\footnotetext{
${ }^{13}$ Andreoni, "Una Nazione in Commercio" Ebrei di Ancona, traffic adriatici e pratiche mercantile in età moderna, 223.
} 


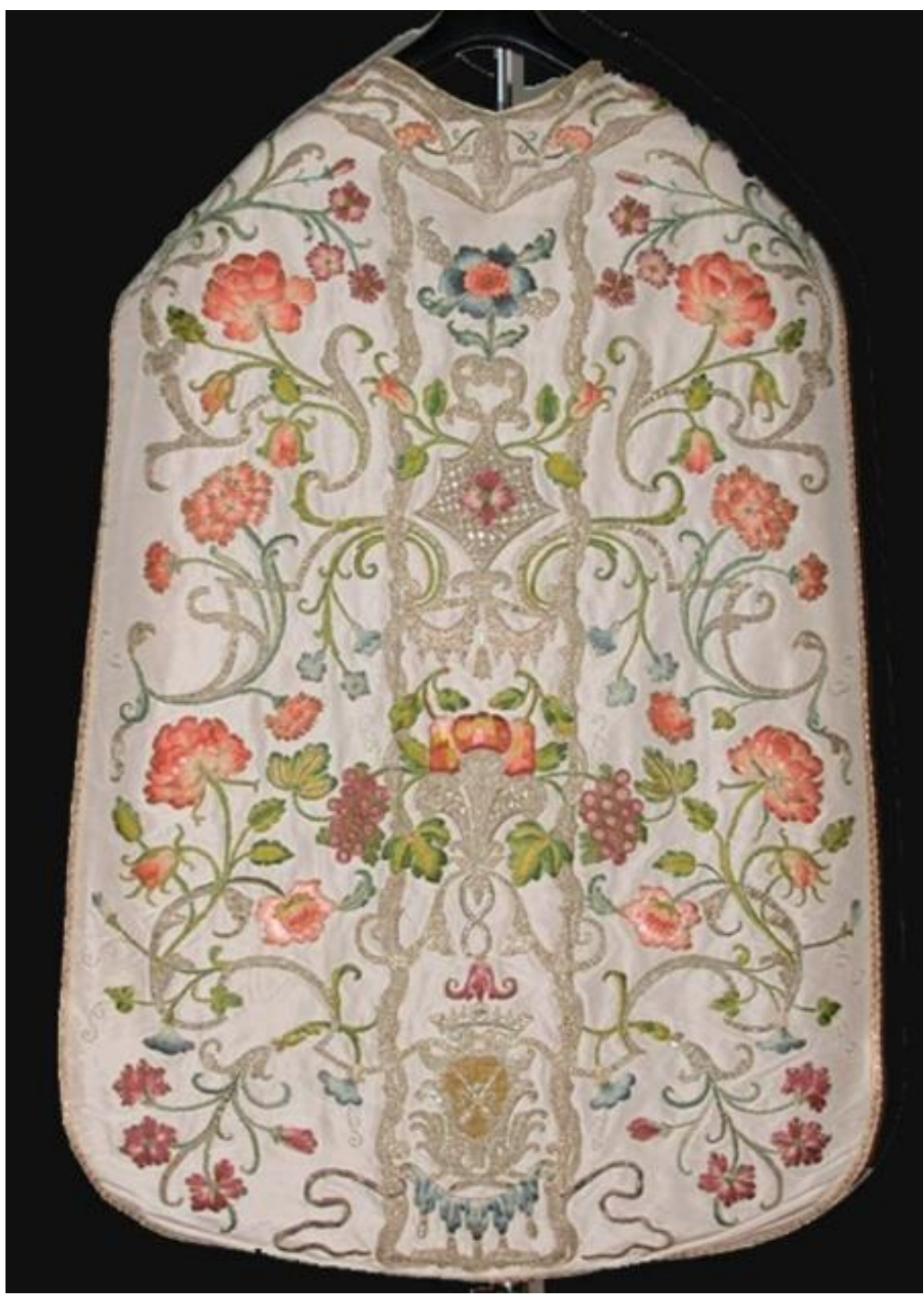

23. Italian, Chasuble, Marche, eighteenth-century,

Inventory of historical and artistic heritage of the diocese of Ancona-Osimo

While bearing elements of rococo naturalism, rather than seemingly picked and strewn, Viterbo's flowers bloom from a central, robust, and convincingly architectural form. The stacked vases supporting rigidly symmetrical volutes and stylized foliage call to mind "Italian" Baroque garden design, digested in the prints of André Mollet or later Daniel Marot. Somewhat old fashioned for 1755, these jardinière designs were nonetheless ever-present in the velvet furnishing fabrics still produced in weaving centers like Genoa and Lyon into the eighteenth century and repurposed on several Torah curtains. The same motifs appear in Jewish metalwork, as evidence by the silver repoussé doors of the Torah Ark in Ancona's Italian Synagogue.

In closing, this free port on the Adriatic, home to a prosperous and cosmopolitan community of Jewish traders, and firmly controlled by a hostile Papacy, provided, perhaps unexpectedly, just the right conditions for Viterbo's skillful creative synthesis. Elements of Baroque garden design, Christian ecclesiastical vestments, botanical naturalism, and Ottoman prayer rugs and embroidery coalesce in the artwork of a young woman confined to a ghetto but connected, through textiles, to networks of trade and exchange from London to the Levant. 
Bibliography

Andreoni, Luca. Una Nazione in Commercio Ebrei di Ancona, traffic adriatici e pratiche mercantile in età moderna. FrancoAngeli, 2019.

"Comment habitaient les Juifs? Patrimoines immobiliers, loyers et sous-loyers dans le ghetto d'Ancone" in Città e Storia. lug-dic 2017, Vol. 12 Issue 2, 201-228.

. Ebrei nelle Marche. Fonti e ricereche (secc. XV-XIX). Il lavoro editoriale, 2012.

_. "Doti e imprese ebraiche mercantili nel Medio Adriatico. Famiglie, capitali, litigi (XVII-XVIII secolo"in I paradigmi della mobilità e delle relazioni : gli ebrei in Italia: in ricordo di Michele Luzzati. Firenze: Giuntina, 2017, 79-111.

Bemporad, Dora Liscia. "Ricamtrici ebree nell'Italia dei ghetti" in Donne nella storia degli ebrei d'Italia. Firenze: Giuntina, 2007.

. Tutti i colori dell'Italia ebraica. Tessuti preziosi dal Tempio di Gerusalemme al prêtà-porter. Catalogo della mostra. Firenze Milano Giunti giugno 2019.

"Jewish Ceremonial Art in the Era of the Ghettos" in Gardens and Ghettos: The Art of Jewish Life in Italy. Berkeley and Los Angeles: University of California Press, 1989.

Di Castro, Daniela, I tesori del Museo ebraico di Roma; guida alla visita e alle collezioni. Roma: Araldo De Luca, 2010.

Dorfman, Rivka and Ben-Zion Dorfman, Synagogues without Jews. Jewish Publication Society, 2000 .

Gasperoni, Michael. "Inheritance and wealth among Jewish women in the ghettos of northcentral Italy (17th-eighteenth centuries)" in Mélanges de l'École française de Rome - Moyen Âge, 130-1, 2018.

Mann, Vivian B. "Textiles Travel: The Role of Sephardim in the Transmission of Textile Forms and Designs" in From Catalonia to the Caribbean: The Sephardic Orbit from medieval to Modern Times. Leiden; Boston: Brill, 2018, 43-59.

Melasecchi, Olga. Antiche mappòt romane: il prezioso archivio tessile del Museo Ebraico di Roma. Roma: Campisano Ediotre, 2017.

The Royal School of Needlework. Book of Embroidery: A Guide to Essential Stitches, Techniques and Projects. Kent, England: Search Press, 2018, 162-177, 212-248.

Viterbo, Yechiel Hayim. Sefer Va-yehi ‘od. Livorno: Otolenghi, 567 [1817 or 1818].

Archives:

Central Archives for the History of the Jewish People, The Hebrew University, Jerusalem 